\title{
REFRACTORY FUNGAL VAGINITIS TREATED BY TOPICAL AMPHOTERICIN B. Review
}

\author{
Falah Hasan Obayes AL-Khikani \\ Department of Microbiology, Al-Shomalli general hospital, Babil,Iraq \\ falahgh38@gmail.com
}

\begin{abstract}
Vaginitis is a common problem for women regarding a worldwide health challenge with many side effects. Vaginitis is among the most visiting to gynecology clinics. About $75 \%$ of all reproductive women had at least one fungal vaginitis infection in their life, and more than $40 \%$ will have two or more than two. Candida spp is the most prevalent in fungal vaginitis, while reports for unusual fungi were observed as mucor spp.

Amphotericin $\mathrm{B}(\mathrm{AmB})$ belongs to the polyene group has a wide spectrum in vitro and in vivo antifungal activity. All of the known available formulas of $\mathrm{AmB}$ are administrated via intravenous injection to treat severe systemic fungal infections, while the development of the topical formula of AmB is still under preliminary development including topical vaginal AmB.

Due to the revealing of antimicrobial-resistant fungi in recent years, this study explains the role of topical AmB in treating refractory fungi vaginitis that may not a response to other drugs reported in many cases that may help researchers to develop new effective formula of AmB regarding fungal vaginitis.
\end{abstract}

Keywords: fungal vaginitis, antifungal drugs, topical Amphotericin B, Amphotericin B formula.

Introduction. Most common women had vaginitis at a certain period in their lives that associated with different ages [1]. Vaginitis is the most predominant infection in the female genital tract and is recognized among women in the primary health centers and gynecology departments. vaginal infections alone account for more than $10 \%$ of patients visit women's health units [2]. Vaginitis is a common term that refers to inflammation of the vaginal wall that caused by one of three causes: fungal yeast infections, trichomoniasis, and bacterial vaginosis [3].

Amphotericin B (AmB) is an ancient agent used over many decades in treating various fungal infections clinically in the human [4]. Low fungal resistance and broad-spectrum antifungal activities are the most valuable pharmaceutical characters encourage continuous usage of AmB [5].

This study highlights the topical efficacy of AmB to treat fungal vaginitis depending on searches and case report studies for rare cases regarding vaginitis.

Advantages of topical AmB. There are many advantages to using $\mathrm{AmB}$ as a topical treatment of dermatophytosis. Firstly, discover new drugs or modification old one will participate to increase the available limited number of antifungal drugs [6]. Secondly, topical preparations are much less costly than orally administered antifungal drugs and cause minimal adverse side effects [7-8].

Third, the application of the topical formula of $\mathrm{AmB}$ considers more safety to use and will not produce clinically relevant serum levels of AmB [8-9]. Fourth, the quality of patient life will increase if new drugs improved to cure infectious lesions in a short time [6].

Topical usage of AmB for refractory fungal vaginitis. Topical modern applications of $\mathrm{AmB}$ provide a promising way of fungal treatment to reduce the adverse effects of intravenous usage of AmB [4]. Five interesting articles have been revealed the role of topical AmB to treat refractory fungal vaginitis (table 1 ).

Phillips was prepared topical vaginal suppositories of $50 \mathrm{mg} \mathrm{AmB}$ showed successful management of $70 \%$ of ten women with non-albicans Candida vaginitis after given nightly for 14 days. Suppositories medicine is also revealed less local side effects and well-tolerated [10].

Topical AmB used in vagina

\begin{tabular}{|l|l|c|l|l|l|l|l|}
\hline Ref & Fungi type & $\begin{array}{c}\text { NO. } \\
\text { patients }\end{array}$ & AmB Dose & AmB formula & $\begin{array}{l}\text { Treatment } \\
\text { duration }\end{array}$ & \multicolumn{1}{|c|}{ Result } & Year \\
\hline 10 & $\begin{array}{l}\text { non-albicans } \\
\text { Candida }\end{array}$ & 32 & $\begin{array}{l}50 \mathrm{mg} \\
\text { nightly }\end{array}$ & $\begin{array}{l}\text { AmB vaginal } \\
\text { suppositories }\end{array}$ & 14 days & $\begin{array}{l}70 \% \text { of women } \\
\text { treated }\end{array}$ & 2005 \\
\hline 11 & $\begin{array}{l}\text { Candida } \\
\text { krusei }\end{array}$ & 1 & $3 \%$ daily & AmB vaginal gell & 14 days & symptoms is resolved & 2016 \\
\hline 12 & $\begin{array}{l}\text { Mucor } \\
\text { species }\end{array}$ & 1 & $\begin{array}{l}3 \% \\
5 \mathrm{~g} \text { daily }\end{array}$ & AmB & 7 weeks & $\begin{array}{l}\text { disappearing of } \\
\text { symptoms, culture-ve }\end{array}$ & 2001 \\
\hline 13 & $\begin{array}{l}\text { Candida } \\
\text { glabrata }\end{array}$ & 3 & $\begin{array}{l}100 \mathrm{mg} \\
\text { once daily }\end{array}$ & $\begin{array}{l}\text { AmB lubricating } \\
\text { jell }\end{array}$ & 2 weeks & $\begin{array}{l}\text { significant } \\
\text { improvement }\end{array}$ & 2001 \\
\hline 14 & $\begin{array}{l}\text { Candida } \\
\text { glabrata }\end{array}$ & 1 & $\begin{array}{l}100 \mathrm{mg} \\
\text { once } \\
\text { Nightly }\end{array}$ & $\begin{array}{l}\text { AmB vaginal } \\
\text { applicator }\end{array}$ & 14 days & $\begin{array}{l}\text { negative culture after } \\
\text { 2 weeks }\end{array}$ & 2003 \\
\hline
\end{tabular}


Chamorro and his colleagues studied the topical formulation of amphotericin $3 \%$ to treat Candida krusei vaginitis was developed by combining amphotericin B deoxycholate with lubricating jelly Aquagel®. Propyleneglycol was used for lubricant incorporation the intravaginal formulation was given daily for 14 days; the patient had resolved her symptoms [11].

Sobel mentioned that $3 \%$ topical amphotericin B $5 \mathrm{~g}$ daily has been used to treat a rare case of vaginitis caused by Mucor species in healthy woman, Mucor vaginitis appeared refractory resistant to flucytosine as well as an azole. The treatment outcome, disappearing of symptoms and she has culture-negative [12].

White et al. found that Flucytosine (one gram) and AmB $(100 \mathrm{mg})$ prepared in lubricating jell were used per vagina once daily to treat vaginal Candida glabrata had failed to respond to antifungals therapy, significant improvement, clinical resolving and negative microbiological culture observed after 2 weeks treatment [13].

Shann and Wilson: the treatment of Candida glabrata resistant to antifungal drugs isolated from vaginal swabs by using vaginal applicator nightly, for 14 days of amphotericin $100 \mathrm{mg}$ plus flucytosine $1 \mathrm{~g}$ in Aquagel. Her symptoms had resolved and culture results for Candida glabrata were negative [14].

Vaginitis prevalence and management. Vaginitis is a widely distributed problem among women mainly associated with discomfort. Symptomatic vaginitis accorded for millions of clinical visits yearly [15]. Vaginitis is a global problem that not just women, but also families and communities.

It may have dangerous complications such as ectopic pregnancy, chronic pelvic pain, abortion, infertility, increasing of HIV transmission, low-birth weight infant. For these reasons, true prevention and management of vaginitis is great important [16].

Candida albicans is responsible for $65-90 \%$ of vaginal Candida species infections, and non-albicans Candida species are responsible for up to $30 \%$ [17]. From 1,740 symptomatic patients, vaginal candidiasis observed in $32,8 \%$ [18].

Candid spp is the leading cause beyond infectious vaginitis; it colonizes about twenty percent of vagina that considered important opportunistic fungal microbe [19]. Vulvovaginal candidiasis (VVC) is the second most commonly reported form of infectious vaginitis. However, the totality of fungal microbes found within the vagina has been grossly underestimation. On the other hand, we have large information about bacteria that harboring vaginal milieu [19].

General features of AmB. Amphotericin $\mathrm{B}(\mathrm{AmB})$ is an ancient agent used over many decades in treating various fungal infections clinically in the human. Opportunistic systemic fungal infection considered the most common type of fungal infection mainly treated by $\mathrm{AmB}$ [4].

At present, many studies focused on the topical preparation of AmB as eye drop [20] or gel [20] or solution [21] or as nanoparticles drug [22]. However, treatment with topical AmB may not always give satisfying results as with ordinary forms of this drug in the treatment of fungal infection, while some topical applications of AmB gave performing outcomes with complete healing especially in certain cases not responded to conventional therapy.

The topical formula of $\mathrm{AmB}$ to treat fungal vaginitis give good results as mentioned in the previous studies, so developing this formula is necessary due to the appearance of drug-resistant fungi implicated in vaginitis.

\section{CONCLUSION}

Vaginitis is one of the most common problems associated with discomfort and low quality of life in women that may make women under serious complications like ectopic pregnancy and abortion. Topical AmB formulas are a promising way to develop effective management of the refractory fungal vaginitis.

Using $\mathrm{AmB}$ in modern branches and new applications is demanded because $\mathrm{AmB}$ is a potential antifungal agent with rare resistance, as well as its broad-spectrum activity toward many fungal infections, more studies about topical AmB vaginal formulas are recommended. Conflicts of interest: authors have no conflict of interest to declare. Надійшла до редакції / Received: 05.06.2020 Прийнято до друку / Accepted: 29.06.2020

\section{REFERENCES}

1. Kimberly A Workowski, Stuart Berman. Sexually transmitted diseases treatment guidelines. Centers for Disease Control and Prevention (CDC). 2015; 64: 1-137. Access mode: https://www.cdc.gov/mmwr/ preview/mmwrhtml/rr6403al.htm

2. Karaer A., Boylu M., Avsar A.F. Vaginitis in Turkish women: symptoms, epidemiologic-microbiologic association // Eur J Obstet Gynecol Reprod Biol. 2005; 121: 211-5. doi: 10.1016/j.ejogrb.2004.11.030. PMID: 16054964

3. Karasz A., Anderson M. The vaginitis monologues: women's experiences of vaginal complaints in a primary care setting // Soc Sci Med. 2003; 56 (5): 1013-21. doi: 10.1016/s0277-9536(02)00092-8. PMID: 12593874.

4. AL-Khikani F.H., AL-Janabi A.A. Topical Amphotericin B formulas: Promising new application // International Journal of Medical Science and Current Research. 2019; 2: 187-96. Access mode: http://www.ijmscr.com/ issue/archive

5. Lanternier F., Lortholary O. Liposomal amphotericin B: what is its role in 2008? // Clinical Microbiology and Infection. 2008; 14 (4): 71-83. DOI: 10.1111/j.14690691.2008.01984.x

6. Scorzoni L., de Paula E. Silva A.C., Marcos C.M., Assato P.A., de Melo W.C., de Oliveira H.C., CostaOriandi C.B., Mendes-Giannini M.J., and FuscoAlmeida A.M. Antifungal therapy: new advances in the understanding and treatment of mycosis // Frontiers in Microbiology. 2017; 8: 1-23. https://doi.org/10.3389/ fmicb.2017.00036 
7. Crawford F., and Hollis S. Topical treatments for fungal infections of the skin and nails of the foot // Cochrane Database of Systematic Reviews. 2007; 3: CD001434. doi: 10.1002/14651858.CD001434.pub2.

8. Hay R. Therapy of skin, hair and nail fungal infections // Journal of Fungi. 2018; 4 (3): 99. https://dx.doi. org/10.3390\%2Fjof4030099

9. Pendleton, R. A., and Holmes IV, J. H. Systemic absorption of amphotericin B with topical $5 \%$ mafenide acetate/amphotericin B solution for grafted burn wounds: Is it clinically relevant? // Burns. 2010; 36 (1): 38-41. https://doi.org/10.1016/j.burns.2009.04.009

10. Phillips A.J. Treatment of non-albicans Candida vaginitis with amphotericin B vaginal suppositories // American journal of obstetrics and gynecology. 2005; 192 (6): 2009-12. https://doi.org/10.1016/j. ajog.2005.03.034

11. Chamorro-de-Vega E., Gil-Navarro M.V., Perez-Blanco J.L. Treatment of refractory Candida krusei vaginitis with topical amphotericin B // Medicina clinica. 2016; 147 (12): 565-6. doi: 10.1016/j.medcli.2016.06.029.

12. Sobel J.D. Vaginal mucormycosis: a case report // Infectious diseases in obstetrics and gynecology. 2001; 9: 117-8. doi: 10.1155/S1064744901000205.

13. White D.J., Habib A.R., Vanthuyne A., Langford S., Symonds M. Combined topical flucytosine and amphotericin B for refractory vaginal Candida glabrata infections // Sexually transmitted infections. 2001; 77 (3): 212-3. https://doi.org/10.1136/sti.77.3.212

14. Shann S., Wilson J. Treatment of Candida glabrata using topical amphotericin B and flucytosine // Sexually transmitted infections 2003; 79 (3): 265-6. https://doi. org/10.1136/sti.79.3.265-a

15. Centers for Disease Control and Prevention. Sexually transmitted disease surveillance 2014. Atlanta (GA): U.S. Department of Health and Human Services; 2015. Access mode: https://wonder.cdc.gov/wonder/help/ STD/STDSurv2014.pdf
16. Centers for Disease Control and Prevention. Genital/ vulvovaginal candidiasis statistics. Retrieved March 27, 2012. Available from: http://www.cdc.gov/disease/ candidiasis/genital/statistics.html)

17. Kennedy MA, Sobel JD. Vulvovaginal candidiasis caused by non-albicans Candida species: new insights // Curr Infect Dis Rep. 2010; 12(6): 465-70. https://www. researchgate.net/deref/http $\% 3 \mathrm{~A} \% 2 \mathrm{~F} \% 2 \mathrm{Fdx}$.doi.org $\% 2$ F10.1007\%2Fs11908-010-0137-9

18. Gaydos CA, Beqaj S, Schwebke JR, Lebed J, Smith B, Davis TE, Fife KH, Nyirjesy P, Spurrell T, Furgerson $\mathrm{D}$, Coleman J. Clinical validation of a test for the diagnosis of vaginitis // Obstetrics and gynecology. 2017; 130 (1): 181. https://dx.doi.org/10.1097\%2FA OG.0000000000002090

19. Bradford LL, Ravel J. The vaginal mycobiome: A contemporary perspective on fungi in women's health and diseases // Virulence. 2017; 8 (3): 342-51. doi: 10.1080/21505594.2016.1237332.

20. Morand, K., Bartoletti, A. C., Bochot, A., Barratt, G., Brandely, M. L., and Chast, F. Liposomal amphotericin $\mathrm{B}$ eye drops to treat fungal keratitis: physico-chemical and formulation stability // International Journal of Pharmaceutics; 2007; 344 (1-2): 150-3. doi: 10.1016/j. ijpharm.2007.04.028.

21. Trasmonte M.V., Jiménez J.D., Santiago M.Á., Gálvez E., Jerez V., Pérez D., and Rubio J. A. Association of topical amphotericin B lipid complex treatment to standard therapy for rhinomaxillary mucormycosis after liver transplantation: a case report // In Transplantation Proceedings. 2012; 44 (7): 2120-3. doi: 10.1016/j. transproceed.2012.07.081

22. Sanchez D.A., Schairer D., Tuckman-Vernon C., Chouake J., Kutner A., Makdisi J., Friedman J.M., Nosanchuk J.D. and Friedman A.J. Amphotericin B releasing nanoparticle topical treatment of Candida spp. in the setting of a burn wound // Nanomedicine: Nanotechnology, Biology and Medicine. 2014; 10 (1): 269-77. doi: 10.1016/j.nano.2013.06.002.

\title{
МІСЦЕВЕ ЛІКУВАННЯ РЕФРАКТЕРНОГО ГРИБКОВОГО ВАГІНІТУ АМФОТЕРИЦИНОМ В. Огляд
}

\section{Фалах Хасан Обайес Аль-Хікані}

\author{
Відділення мікробіологї, лікарня Аль-Шомаллі, Бабіль, Ірак \\ falahgh38@gmail.com
}

\footnotetext{
Резюме. Вагініт є загальною проблемою для жінок у всьому світі, з багатьма побічними ефектами. Вагініт - одна $з$ найбільш розповсюджених причин відвідування гінекологічних клінік. Близько $75 \%$ всіх репродуктивних жінок мали принаймні одну грибкову вагінітну інфекцію у своєму житті, а понад $40 \%$ - дві або більше двох. Candida spp є найбільш поширеним при грибковому вагініті, тоді як повідомлення про незвичні гриби спостерігалися як mucor spp.

Амфотерицин В (AmB) відноситься до полієнової групи, має широкий спектр in vitro та in vivo протигрибкової активності. Всі відомі доступні формули АmB вводяться за допомогою внутрішньовенної ін'єкції для лікування важких системних грибкових інфекцій, тоді як розробка актуальної формули $\mathrm{AmB}$ ще знаходиться на стадії попередньої розробки, включаючи місцевий вагінальний AmB.

Завдяки виявленню антимікробних стійких грибів в останні роки, це дослідження пояснює роль актуального АmВ у лікуванні рефрактерного грибкового вагініту, що може не відповідати на інші препарати, про які повідомляється у багатьох випадках, які можуть допомогти дослідникам розробити нову ефективну формулу АmB щодо грибкового вагініту.

Ключові слова: грибковий вагініт, протигрибкові препарати, амфотерицин В місцево, формула амфотерицину В.
} 
МЕСТНОЕ ЛЕЧЕНИЕ РЕФРАКТЕРНОГО ГРИБКОВОГО ВАГИНИТА АМФОТЕРИЦИНОМ В. Обзор

\section{Фалах Хасан Обайес Аль-Хикани}

\section{Отделение микробиологии, больнича Аль-Шомалли, Бабил, Ирак}

$$
\text { falahgh38@gmail.com }
$$

Резюме. Вагинит является распространенной проблемой для женщин во всем мире, со многими побочными эффектами. Вагинит является одним из самых распростанённых причин посещения гинекологических клиник. Около $75 \%$ всех репродуктивных женщин имели, по крайней мере, одну грибковую инфекцию вагинита в своей жизни, и более $40 \%$-две или более двух. Candida spp является наиболее распространенным при грибковом вагините, в то время как сообщения о необычных грибах наблюдались как mucor spp.

Амфотерицин В (AmB) относится к полиеновой группе, обладает широким спектром противогрибковой активности in vitro и in vivo. Все известные доступные формулы $\mathrm{AmB}$ вводятся посредством внутривенной инъекции для лечения тяжелых системных грибковых инфекций, в то время как разработка местной формулы АmB все еще находится в стадии предварительной разработки, включая актуальный вагинальный $\mathrm{AmB}$.

В связи с выявлением устойчивых к противомикробным препаратам грибов в последние годы, это исследование объясняет роль местного $\mathrm{AmB}$ в лечении рефрактерного грибкового вагинита, который во многих случаях может не реагировать на другие препараты, о которых сообщалось, что может помочь исследователям разработать новую эффективную формулу АmB в отношении грибкового вагинита.

Ключевые слова: грибковый вагинит, противогрибковые препараты, амфотерицин В местно, формула амфотерицина В. 